\title{
Effect of Unemployment Rate on Growth Rate of Gross Domestic Product of Jordan
}

\author{
Khaled Abdalla Moh'd AL-Tamimi ${ }^{1}$ \\ ${ }^{1}$ Department of Financial and Administrative Sciences, Irbid University College, Al-Balqa' Applied University, \\ Jordan \\ Correspondence: Dr. Khaled Abdalla Moh'd AL-Tamimi, Associate professor, Department of Financial and \\ Administrative Sciences, Irbid University College, Al-Balqa' Applied University, Jordan.
}

Received: June 23, 2019

doi:10.5430/rwe.v10n3p217
Accepted: September 30, $2019 \quad$ Online Published: November 29, 2019

URL:https://doi.org/10.5430/rwe.v10n3p217

\begin{abstract}
This study explains the effect of unemployment rate on growth rate of GDP of Jordan by depending on yearly data for the period (2009 - 2016) as unemployment rate is independent variable, and growth rate of GDP (Avariable of economic growth) as a dependent variable. This study focuses on explaining the literature both in theoretical and empirical ways of the effect of unemployment rate on growth rate of GDP, and analyzing the effect of unemployment rate on growth rate of GDP of Jordan by depending on yearly data for the period (2009 - 2016) by using the technique of ordinary least squares in version of E-views. This paper found that there are insignificant impacts of unemployment percentage to total labor force, unemployment of males percentage to male labor force, unemployment of females percentage to female labor force on growth rate of GDP of Jordan by relying on yearly data for the period 2009 to 2016 at level of significance 5\%. This paper recommends testing the impacts of other obstacles in Jordan on growth rate on GDP, in order to know the variables that effect growth rate of GDP in Jordan.
\end{abstract}

Keywords: unemployment rate, economic growth rate, gross domestic product, labor force

\section{Introduction}

Unemployment is a variable that has a lot of dimension; unemployment is an economic variable that results in existing imbalances in the economic society. It is also a social variable as it has a lot of impacts on the social lives of people in the society. These dimensions cause a difficulty in understanding the effects of unemployment. Economic growth is an objective that countries want to enhance for fiscal and monetrary policies (Al-Habees and Abu Rumman, 2012, p. 673).

The relationship of unemployment rate and economic growth shows from the negative impact of unemployment on economic growth as the higher the unemployment, the less the ways to enhance economic growth of the society and vice versa (Al-Habees and Abu Rumman, 2012, p. 673).

The best solution for unemployment and its effect on unemployment is changing economic ways and policies to enhance the economic growth and that has a positive effect on lowering levels of unemployment ratesas these policies create a lot of jobs by making a lot of investment projects (Al-Habees and Abu Rumman, 2012, p. 673).

Based on the above introduction, this paper analyzes the effect of unemployment rate on growth rate of GDP of Jordan by dependingon yearly data for the period $(2009-2016)$, by explaining the literature both in theoretical and empirical ways of the effect of unemployment rate on growth rate of GDP, and analyzing the effect of unemployment rate on growth rate of GDP of Jordan by relying on yearly data for the period $(2009-2016)$ by depending on using the method of ordinary least squares in version of E-views.

\section{Importance of the Study}

The effect of unemployment on growth rate of GDP can be shown by these negative effects as follows:

- Labour exploitation: as a result of unemployment, there is exploitation of labours. They have to agree with decreasing salaries and wages and working in an environment they do not like. 
- Disputes in the industrial field: these disputes come from rising unemployment rate. It has bad impacts on the relations between employees and employers. These disputes also have bad effects on unemployment rates (Kum, Aslan and Gungor, 2015, p. 1075).

- Instability in the political system: the instability in the political system arises from unemployment in the country. As unemploymed people enter into destructive projects and the economic growth will be difficult because of rising unemployment rates in the country.

- Problems and obstacles in the social life: the problems and obstacles in the social life such as immortality, dishonesty ... etc arise from rising unemployment in the country, these problems lead to social disruption in the state.

- Raising poverty: rising unemployment in the country leads to inexistence of any source of income for people, so it leads to poverty, increasing burden of debt and rising economic obstacles and problems.

- Lack of human resources: rising unemployment rates in the country leads to loss of human resources and that leads to decreasing economic growth in the country (Makaringe and Khobai, 2018, pp. 2 - 3) and (Anghel, Anghelache, and Manole, 2017, pp. 174 - 175).

In the end of theoretical literature and from the effects of rising unemployment rates on growth rate of GDP, we can say that this effect is bad and negative as the higher the unemployment rate, the lower the economic growth in the country and vice versa (Makaringe and Khobai, 2018, p. 3).

\section{Literature Review}

There are a lot of studies that study the effect of unemployment on growth rate of GDP as follows:

1- (Shahid, 2014) paper that focuses on studying the impact of unemployment rate on growth rate of GDP in Pakistanby relying on annual data for the period from1980 to 2010 by depending on estimation ofAuto Regressive Distribution Lag (ARDL). This paper reached that there is a relationship between unemployment rate and growth rate of GDP in Pakistan in the long run for the period of this paper.

2- (Makaringe and Khobai, 2018) paper focuses on analyzing the effect of unemployment rate on growth rate of GDP in South Africa by relying on quarterly data during the period (the first quarter of 1994- the fourth quarter of 2016) by depending on estimation of Auto Regressive Distribution Lag (ARDL). This study reached a relation between unemployment rate and growth rate of GDP and a negative effect of unemployment rate on growth rate of GDP in both the long run and the short run.

3- (Seth, John and Dalhatu, 2018) paper focuses on analyzing the impact of unemployment rate on growth rate of GDP in Nigeria by relying onyearly data for the period from 1986 to 2015 by depending on estimation of Auto Regressive Distribution Lag (ARDL). This paper reached that there is no relationship between unemployment rate and growth rate of GDP in Nigeria and there is a positive effect of unemployment rate on growth rate of GDP in the third period in the informal sector.

4- (Dritsakis and Stamatiou, 2016) paper that focuses on analyzing the effect of unemployment rate on growth rate of GDP for Greece by relying on yearly data for the period1995 to 2015 by depending on estimation of Auto Regressive Distribution Lag (ARDL). This paper found a relation between unemployment rate and growth rate of GDP in the long run and short run and there is a unidirectional causal effect of unemployment to growth rate of GDP.

5- (Yahaya Enejoh and Tsauni, 2017) paper focuses on studying the effect of unemployment rate on growth rate of GDP for Nigeria by relying on yearly data for the period 1970 to 2016 by depending on Johanson Cointegration Estimation and Error Correction models. This study found that there is a relationship between unemployment rate and growth rate of GDP in the long run in Nigeria, there is a positive effect of unemployment rate on growth rate of GDP in the long run and short run and there is a unidirectional causality from unemployment to growth rate of GDP.

6- (Omitogun and Longe, 2017) study that analyzes the effect of unemployment rate on growth rate of GDP in Nigeria by relying on yearly data for the period 1986 to 2015 by using estimation of a Vector Auto regressive (VAR) approach. This study found that there is an effect of unemployment rate on growth rate of GDP, but it decreased over time because of the efforts of government in Nigeria towards decreasing unemployment rate. 
7- (Soylu, Cakmak, and Okur, 2018) paper studies the influence of unemployment rate on growth rate of GDP in some Eastern European countries by relying on yearly data for the period 1992 to 2014 by depending on panel OLS and panel Johansen cointegration test and this paper reaches that there is a relationship between these two variables in the long run and economic growth has a positive effect on unemployment rate in these countries.

8- (Jajere, 2016) paper that focuses on analyzing the effect of unemployment rate on growth rate of GDP in Nigeria by relying on yearly data for the period from 1980 to 2010 by relying on Ordinary least squares regression method and this paper reaches that unemployment does not have any effect on growth rate of GDP in Nigeria for this period.

9- (Thayaparan, 2014) paper focuses on analyzing the relationship between unemployment rate and growth rate of GDP in Sri Lanka by relying on yearly data for the period 1990 to 2012 by depending on Ordinary least squares method. This study reached that growth rate of GDP has insignificant impact on unemployment rate, but there is bidirectional causality between growth rate of GDP and unemployment in Sri Lanka.

Most of the above papers found a positive effect of economic growth on unemployment rate, but negative impact of unemployment rate on economic growth. These studies lack analyzing the effects of sorts of unemployment (unemployment rates of males and females) on economic growth. In this context, this study will focus on this point in analyzing the effect of unemployment rate on economic growth in Jordan.

\section{Effect of Unemployment Rateon Growth Rate of GDP of Jordan by Depending on Yearly Data for the Period 2009 to 2016}

\subsection{Method}

This study relies on yearly data for the period 2009 to 2016 for unemployment percentage to total labor force, unemployment of males percentage to male labor force, unemployment of females percentage to female labor forceand growth rate of GDP variables of Jordan. The coming equation represents the impact of unemployment rate on growth rate of GDP of Jordan:

$$
\begin{aligned}
& \text { Economic growt } h_{t} \\
& =\alpha_{0}+\alpha_{1} \text { unemployment percentage to total labor force } t \\
& +\alpha_{2} \text { unemployment of males percentage to male labor force } e_{t} \\
& +\alpha_{3} \text { unemployment of females percentage to female labor force } e_{t}+\varepsilon_{t}
\end{aligned}
$$

\subsection{Results}

This partition analyzes unemployment percentage to total labor force, unemployment of males percentage to male labor force, unemployment of female spercentage to female labor forceand growth rate of GDP variables of Jordan by relying on yearly data for the period 2009 to 2016as follows:

\subsubsection{Unemployment Percentage to Total Labor Force for Jordan}

Table 1. Unemployment percentage to total labor force of Jordan by depending on yearly data for the period 2009 to 2016

\begin{tabular}{lc}
\hline Year & $\begin{array}{c}\text { Unemployment percentage to total } \\
\text { labor force }\end{array}$ \\
\hline 2009 & 12.9 \\
2010 & 12.5 \\
2011 & 12.9 \\
2012 & 12.2 \\
2013 & 12.6 \\
2014 & 11.9 \\
2015 & 13.1 \\
2016 & 15.3 \\
\hline
\end{tabular}

Source: Researcher designing by depending on data of World Bank 


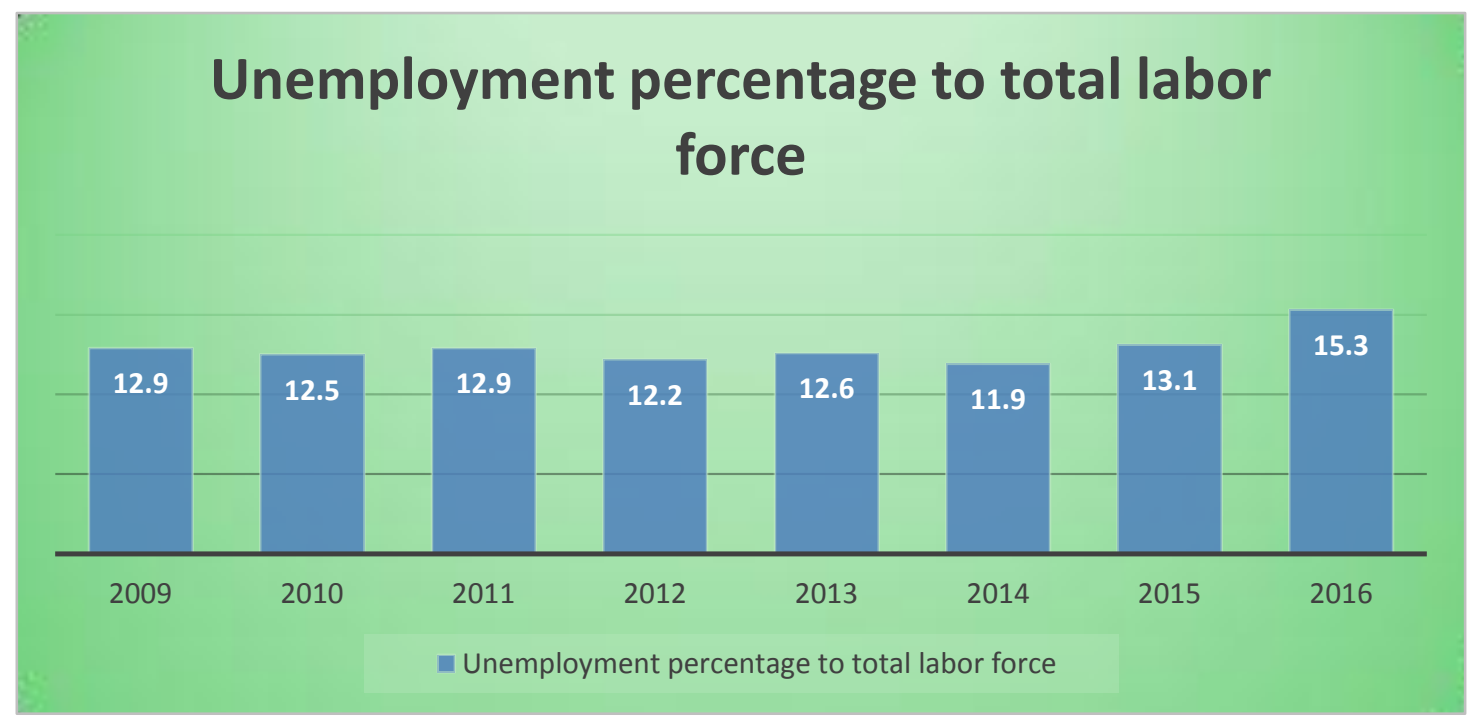

Figure 1. Unemployment percentage to total labor force of Jordan by depending on yearly data for the period 2009 to 2016

Source: Researcher designing by depending on data of World Bank

The above table and figure reflect that there is a fluctuation in unemployment percentage to total labor force of Jordan by relying on yearly data for the period 2009 to 2016 . Totally, they show there is increase in unemployment percentage to total labor force to $15.3 \%$ in 2016.

4.2.2 Unemployment of Males Percentage to Male Labor Force of Jordan

Table 2. Unemployment of males percentage to male labor force of Jordan by depending on yearly data for the period 2009 to 2016

\begin{tabular}{lc}
\hline Year & $\begin{array}{c}\text { Unemployment of males } \\
\text { percentage to male labor force }\end{array}$ \\
\hline 2009 & 10.3 \\
2010 & 10.4 \\
2011 & 11 \\
2012 & 10.4 \\
2013 & 10.6 \\
2014 & 10.1 \\
2015 & 11 \\
2016 & 13.3 \\
\hline
\end{tabular}

Source: Researcher designing by depending on data of World Bank 


\section{Unemployment of males percentage to male labor force}

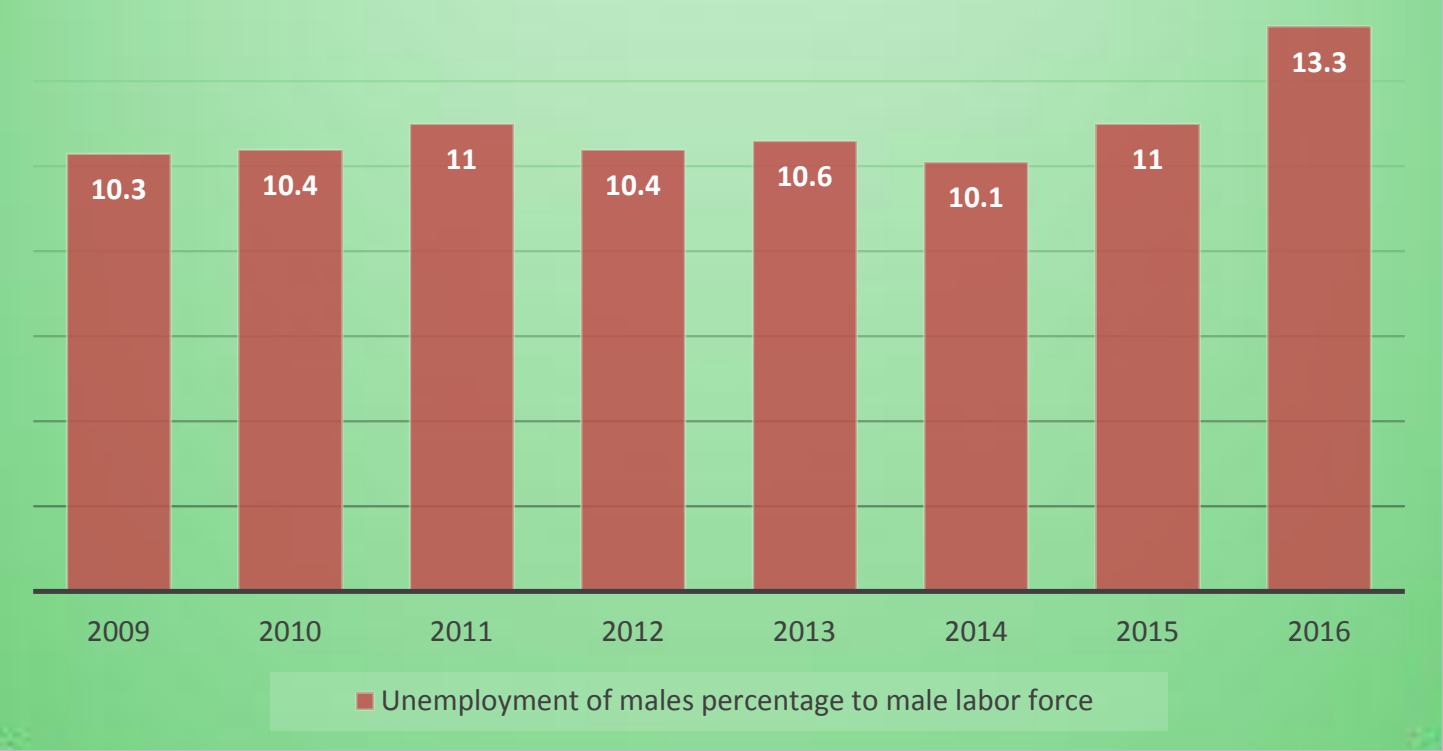

Figure 2. Unemployment of males percentage to male labor force of Jordan by depending on yearly data for the period 2009 to 2016

Source: researcher designing by depending on data of World Bank

The above table and figure reflect that there is a fluctuation in the unemployment of males percentage to male labor force of Jordan by relying on yearly data for the period 2009 to 2016. Totally, they refer to that the unemployment of males percentage to male labor force increases to $13.3 \%$ in 2016.

4.2.3 Unemployment of Females Percentage to Female Labor Force of Jordan

Table 3. Unemployment of females percentage to female labor force of Jordan by depending on yearly data for the period 2009 to 2016

\begin{tabular}{lc}
\hline Year & $\begin{array}{c}\text { Unemployment of females } \\
\text { percentage to female labor force }\end{array}$ \\
\hline 2009 & 24.1 \\
2010 & 21.7 \\
2011 & 21.2 \\
2012 & 19.9 \\
2013 & 22.2 \\
2014 & 20.7 \\
2015 & 22.5 \\
2016 & 24.1 \\
\hline
\end{tabular}

Source: Researcher designing by depending on data of World Bank 


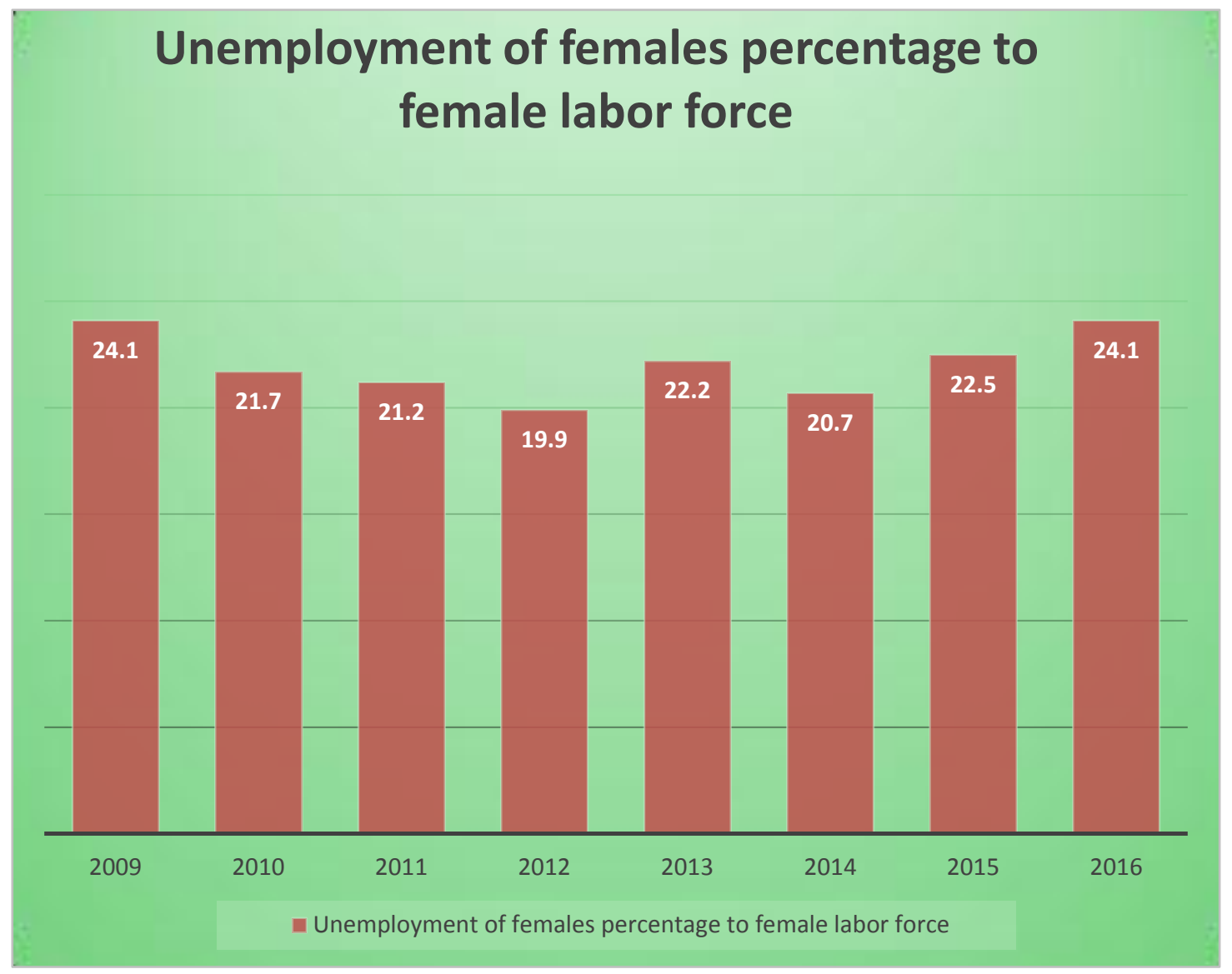

Figure 3. Unemployment of females percentage to female labor force of Jordan by depending on yearly data for the period 2009 to 2016

Source: researcher designing by depending on data of World Bank

The above table and figure reflect that there is a fluctuation in the Unemployment of females percentage to female labor force of Jordan for Jordan by depending on yearly data for the period 2009 to 2016 . Totally, they show that the Unemployment of females percentage to female labor force of Jordan increases to $24.1 \%$ in 2016.

4.2.4 Growth Rateof GDP (As an Indication of Economic Growth) of Jordan

Table 4. Growth rate of GDP of Jordan by relying on yearly data for the period 2009 to 2016

\begin{tabular}{lc}
\hline Year & $\begin{array}{c}\text { Growth rate of } \\
\text { GDP }\end{array}$ \\
\hline 2009 & 5.2 \\
2010 & 0.004 \\
2011 & 2.5 \\
2012 & 2.3 \\
2013 & 3.1 \\
2014 & 3 \\
2015 & 2.4 \\
2016 & 2.3 \\
\hline
\end{tabular}

Source: Researcher designing by depending on data of World Bank 


\section{Growth rate of GDP}

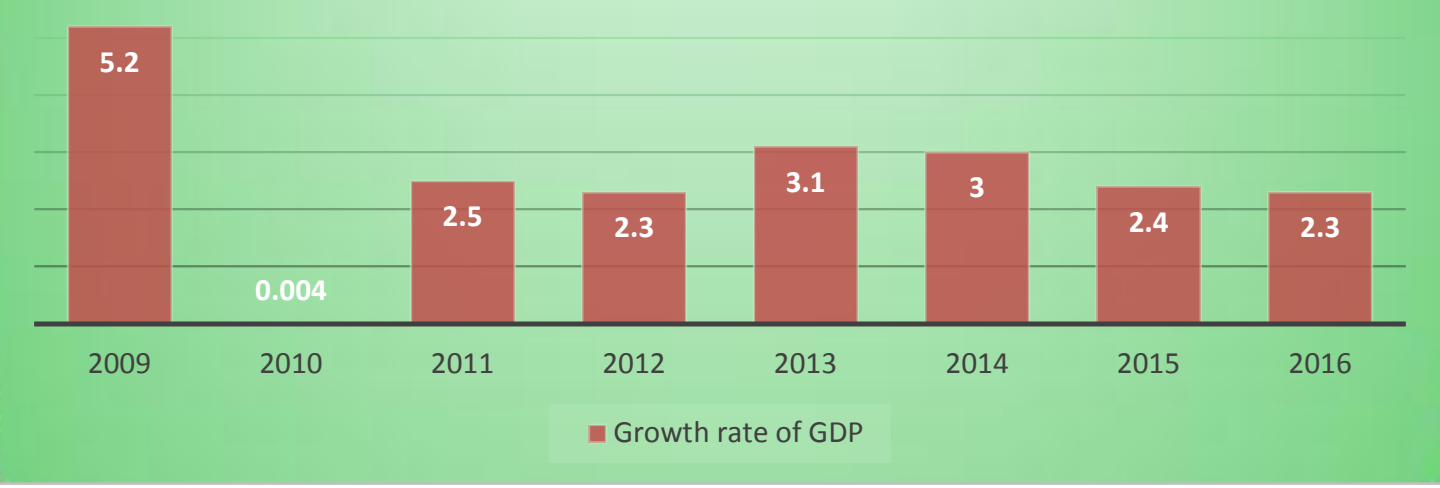

Figure 4. Growth rate of GDP of Jordan by dependig on yearly data for the period from 2009 to 2016

Source: Researcher designing by depending on data of World Bank

Table and figure above reflect growth rate of GDP of Jordan by relying on yearly data for the period 2009 to 2016 . They indicate that growth rate of GDP increases for the first section of period from $0.004 \%$ in 2010 to $3.1 \%$ in 2013 , but it decreases through the second section of this period to $2.3 \%$ in 2016. To know the impact of unemployment rate on growth rate of GDP, the researcher uses the following:

\section{Discussion}

The below figure reflects the impact of unemployment rate on growth rate of GDP of Jordan by relying on yearly data for the period 2009 to 2016 as follows:

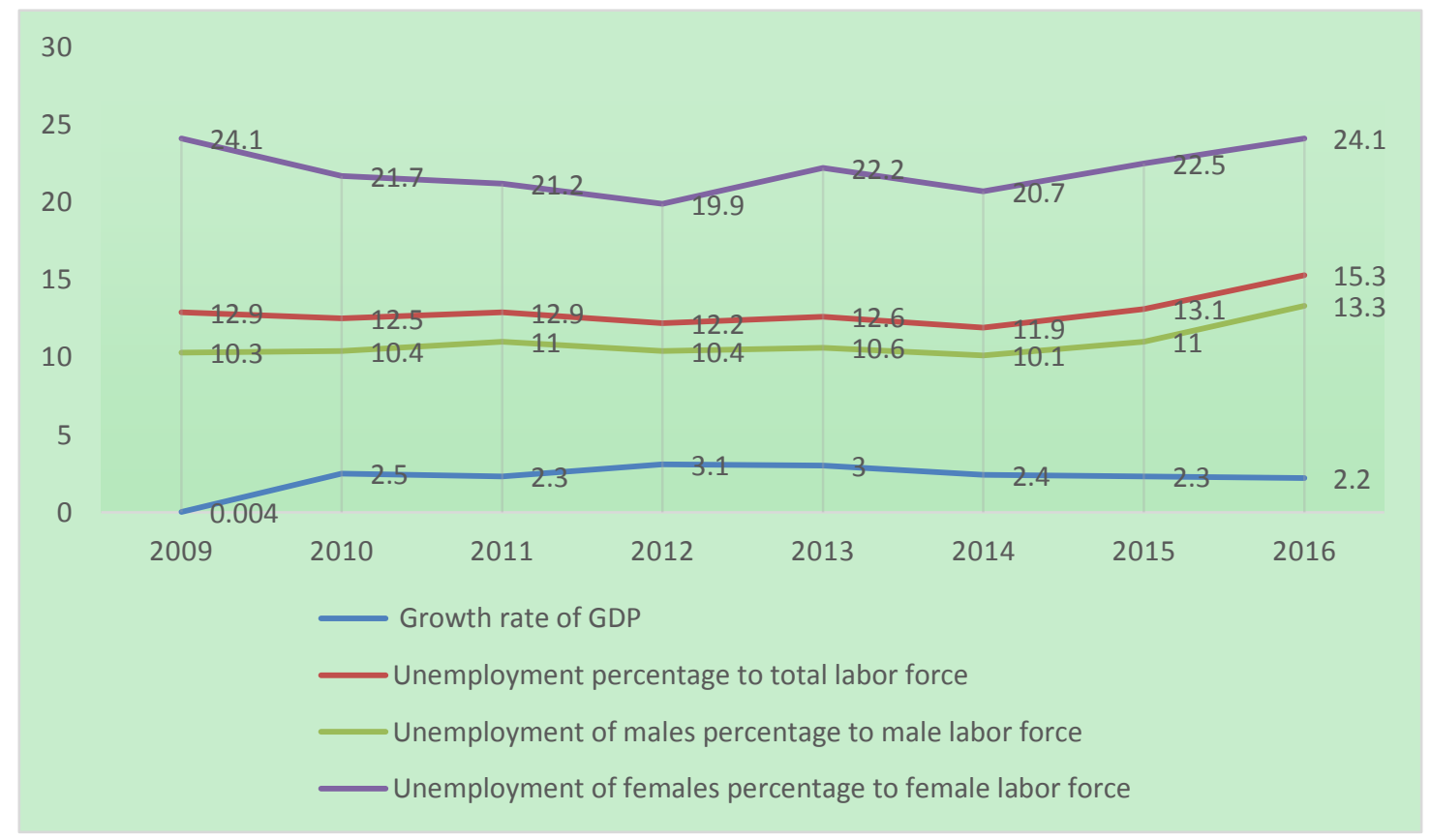

Figure 5. Unemployment rateand Growth rate of GDP of Jordan by relying on yearly data for the period from 2009 to 2016

Source: Researcher designing by depending on data of World Bank 
Figure 5 refers to the impact of unemployment percentage to total labor force, unemployment of males percentage to male labor force, unemployment of females percentage to female labor force on growth rate of GDP of Jordan by relying on yearly data for the period 2009 to 2016 . The above figure refers to a negative impact of unemployment percentage to total labor force, unemployment of males percentage to male labor force, unemployment of females percentage to female labor force on growth rate of GDP of Jordan; as if unemployment rates raise, growth rate of GDP decreases and vice versa. To trust this impact, the study relies on ordinary least squares technique to know the impact of unemployment percentage to total labor force, unemployment of males percentage to male labor force, unemployment of females percentage to female labor force on growth rate of GDP of Jordan by depending on yearly data for the period 2009 to 2016 as follows:

\begin{tabular}{|c|c|c|c|c|}
\hline \multicolumn{5}{|c|}{$\begin{array}{l}\text { Dependent Variable: GRO } \\
\text { Method: Least Squares } \\
\text { Sample: } 20092016 \\
\text { Included observations: } 8\end{array}$} \\
\hline Prob. & t-Statistic & Std. Error & Coefficient & Variable \\
\hline 0.8209 & -0.241723 & 7.382726 & -1.784577 & UNEM \\
\hline 0.9031 & 0.129703 & 6.130174 & 0.795105 & MAUNEM \\
\hline 0.5553 & 0.642882 & 1.493441 & 0.960106 & FEUNEM \\
\hline 0.6683 & -0.461709 & 9.011908 & -4.160881 & $\mathrm{C}$ \\
\hline \multicolumn{3}{|c|}{ 2.600500Mean dependent var } & \multicolumn{2}{|c|}{$0.326633 \mathrm{R}$-squared } \\
\hline \multicolumn{3}{|c|}{ 1.421228S.D. dependent var } & \multicolumn{2}{|c|}{-0.178392 Adjusted R-squared } \\
\hline \multicolumn{3}{|c|}{ 4.011922 Akaike info criterion } & \multicolumn{2}{|c|}{ 1.542796S.E. of regression } \\
\hline \multicolumn{3}{|c|}{ 4.051643 Schwarz criterion } & \multicolumn{2}{|c|}{ 9.520876Sum squared resid } \\
\hline \multicolumn{3}{|c|}{ 3.744022 Hannan-Quinn criter. } & \multicolumn{2}{|c|}{-12.04769Log likelihood } \\
\hline \multicolumn{3}{|c|}{ 2.727905 Durbin-Watson stat } & \multicolumn{2}{|c|}{0.646767 F-statistic } \\
\hline & & & \multicolumn{2}{|c|}{ 0.624770Prob(F-statistic) } \\
\hline
\end{tabular}

The above table refers to that there are insignificant impacts of unemployment percentage to total labor force, unemployment of males percentage to male labor force, unemployment of females percentage to female labor force on growth rate of GDP of Jordanby relying on yearly data for the period 2009 to 2016 at level of significance 5\%.

\section{Conclusion and Recommendations}

This paper analyzes the impact of unemployment rates on growth rate of GDP in the literature both theoretically and empirically, and this impact in Jordan by depending on yearly data for the period 2009 to 2016. This study reached insignificant impacts of unemployment percentage to total labor force, unemployment of males percentage to male labor force, unemployment of females percentage to female labor force on growth rate of GDP of Jordan by relying on yearly data for the period 2009 to 2016 at level of significance 5\%.

This study recommends testing the impacts of other obstacles on growth rate on GDP in Jordan, in order to know the variables that effect growth rate of GDP in Jordan. This recommendation can benefit decision makers in achieving economic growth in Jordan, as they know that unemployment rate has an insignificant effect on economic growth. In this context, researchers should conduct more researches of other variables those have effects on economic growth in Jordan.

\section{References}

Al-Habees, M., \& Abu Rumman, M. (2012). The Relationship between Unemployment and Economic Growth in Jordan and Some Arab Countries. World Applied Sciences Journal, 18(5), 673-680. Retrieved from https://pdfs.semanticscholar.org/95c3/7e58c6b350dd0eb30e7bfdeb53d6c524564a.pdf 
Anghel, M., Anghelache, C., \& Manole, A. (2017). The Effect of Unemployment on Economic Growth. Romanian Statistical Review, (7), Retrieved 174-186. http://www.revistadestatistica.ro/supliment/wpcontent/uploads/2017/07/rrss_07_2017_A8_en.pdf

Dritsakis, N., \&Stamatiou, P. (2016). The Effects of Unemployment on Economic Growth in Greece. An ARDL Bound Test Approach. The Romanian Economic Journal, (62), 53-72. Retrieved from http://www.rejournal.eu/sites/rejournal.versatech.ro/files/articole/2017-01-03/3405/3dritsakis.pdf

Jajere, H. (2016). Impact of Unemployment on Economic Growth in Nigeria 1980 - 2010. Pyrex Journal of Business and Finance Management Research, 2(10), 180-195. Retrieved from https://www.pyrexjournals.org/pjbfmr/pdf/2016/december/Jajere.pdf

Makaringe, S., \& Khobai, H. (2018). The effect of unemployment on economic growth in South Africa (1994-2016). Munich Personal RePEc Archive. Retrieved from https://mpra.ub.uni-muenchen.de/85305/1/MPRA_paper_85305.pdf

Omitogun, O., \&Longe, A. (2017). Unemployment and Economic Growth in Nigeria in the 21st Century: VAR $\begin{array}{lllll}\text { Approach. } & A U D O E, & 13(5), & \text { Retrieved }\end{array}$ http://journals.univ-danubius.ro/index.php/oeconomica/article/viewFile/4064/4256

Seth, A., John, M., \&Dalhatu, A. (2018). The Impact of Unemployment on Economic Growth in Nigeria: An Application of Autoregressive Distributed Lag (ARDL) Bound Testing. Sumerianz Journal of Business Management and Marketing, 1(2), 37-46. Retrieved from https://www.sumerianz.com/pdf-files/sjbmm1(2)37-46.pdf

Shahid, M. (2014). Effect of Inflation and Unemployment on Economic Growth in Pakistan. Journal of Economics and Sustainable Development, $\quad$ 5(15). from https://pdfs.semanticscholar.org/cfef/a5fd68fd8a7f9e8e95d6ebd3955d28a9c678.pdf

Soylu, O., Cakmak, I., \& Okur, F. (2018). Economic growth and unemployment issue: Panel data analysis in Eastern European Countries. Journal of International Studies, $11(1)$, 93-107. https://doi.org/10.14254/2071-8330.2018/11-1/7

Thayaparan, A. (2014). Impact of Inflation and Economic Growth on Unemployment in Sri Lanka: A Study of Time Series Analysis. Global Journal of Management and Business Research: B Economics and Commerce, 13(5). Retrieved from https://globaljournals.org/GJMBR_Volume14/5-Impact-of-Inflation-and-Economic.pdf

YahayaEnejoh, S., \&Tsauni, A. (2017). An Analytical Study of the Impact of Unemployment on Economic Growth in Nigeria (1970-2016). IOSR Journal of Humanities and Social Science (IOSR-JHSS), 22(11), Ver. 7, 74-81. Retrieved from http://www.iosrjournals.org/iosr-jhss/papers/Vol.\%2022\%20Issue11/Version-7/I2211077481.pdf 